\title{
Effects of cold winters and climate on the temporal variability of an epibenthic community in the German Bight
}

\author{
Hermann Neumann ${ }^{1, *}$, Siegfried Ehrich ${ }^{2}$, Ingrid Kröncke ${ }^{1}$ \\ ${ }^{1}$ Senckenberg Institute, Department for Marine Research, Südstrand 40, 26382 Wilhelmshaven, Germany \\ ${ }^{2}$ Johann Heinrich von Thünen Institute, Institute for Sea Fisheries, Palmaille 9, 22767 Hamburg, Germany
}

\begin{abstract}
Benthic epifauna was sampled in an area of $10 \times 10$ nautical miles in the German Bight. Samples were collected in January and July/August from 1998 to 2007 with a standard 2 m beam trawl. The epibenthic communities were severely affected by the cold winter in 1995-1996, which also resulted in high abundance and biomass of the opportunistic brittle star Ophiura albida, in connection with low diversity observed at the beginning of our study period. In the following years winter bottom temperature increased simultaneously with the decrease of $O$. albida and the increase in abundance and biomass of other species. It appears that these changes were caused by trophic interactions as well as mild winters, which resulted in lower mortality, higher reproduction and higher food supply for benthic fauna due to enhanced primary production. Additionally diversity increased and species such as Astropecten irregularis, Corystes cassivelaunus, Crangon crangon and Crangon allmanni revealed distinct seasonal patterns caused by migration, mortality and reproduction cycles. The changes in community structure are discussed in relation to the general warming trend of the North Sea, which is linked to a phase of continuously increasing North Atlantic Oscillation Index (NAOI) since the late 1980s. We found evidence that climatic variability influenced recruitment success, mortality and migration patterns of epifaunal species.
\end{abstract}

KEY WORDS: Epifauna $\cdot$ North Sea $\cdot$ Temperature $\cdot$ Climate $\cdot$ NAOI $\cdot$ Cold winter $\cdot$ Mild winter Succession Resale or republication not permitted without written consent of the publisher

\section{INTRODUCTION}

There is much evidence that marine ecosystems have been influenced by climate fluctuations on a large scale (Ottersen et al. 2001, Stenseth et al. 2002). In the North Sea ecosystem, a regime shift occurred in the late 1980s that affected most trophic levels including phytoplankton, zooplankton, benthic infauna as well as fish and birds (Reid \& Edwards 2001). These changes were linked to a phase of continuously increasing North Atlantic Oscillation Index (NAOI after Hurrel 1995) since the late 1980s that was associated with increasing westerly winds, Atlantic inflow and increasing sea-surface temperature (SST) (Kröncke et al. 1998, Edwards et al. 2002, Reid et al. 2003). Synchronous changes in marine ecosystems were also ob- served in the Baltic Sea and on an Atlantic-wide scale (Alheit et al. 2005, Reid 2005).

However, the trend of increasing NAOI which commenced in the late 1980s was interrupted by the reversal of the index in 1995-1996 resulting in cold winter conditions in the North Sea region. Severe winters were linked to low NAOI values leading to fewer and weaker winter storms crossing the Atlantic Ocean in more of a west-east pathway and resulting in cold winter temperatures in North Europe (Hurrell 1995). There is a large body of literature revealing that severe winters affect benthic infauna, often dramatically. This is reflected in decreasing species number, abundance and biomass, often due to the direct influence of temperature on the mortality of species (Ziegelmeier 1970, Buchanan \& Moore 1986, Beukema 1992, Kröncke et 
al. 1998, Reiss et al. 2006b). In contrast, little is known about the effects of severe winters on epifauna communities. Compared to the relatively stationary infauna, the benthic epifauna is more mobile and may, thus, be able to avoid unfavourable conditions, which is reflected in strong seasonal migration patterns of species (Boddeke 1976, Choy 1991, Freeman et al. 2001).

We started an epifauna time series in 1998, 3 years after the severe winters of 1995-1996. Our data provide new information concerning the effect of severe winters on an epifauna community in the German Bight, and the subsequent recovery of the community. With respect to the climate debate, our aim was to assess the influence of mild winters, in conjunction with increasing water temperatures, on the seasonal and annual variability of epifauna in the German Bight.

\section{METHODS AND DATA}

The $10 \times 10$ nautical mile (n mile) area of investigation was situated about $25 \mathrm{n}$ miles northwest of the Island of Helgoland, in close proximity to the $30 \mathrm{~m}$ depth contour near the former glacial valley of the River Elbe $\left(54^{\circ} 17^{\prime}\right.$ to $54^{\circ} 27^{\prime} \mathrm{N}$ and $006^{\circ} 58^{\prime}$ to $007^{\circ} 15^{\prime} \mathrm{E}$ ) (Fig. 1). The mean depth of this area is $40 \mathrm{~m}$ and the water column is generally well mixed throughout the year. The sediments in the study area consist of $>20 \%(<63 \mu \mathrm{m}$ fraction) mud in the south-west corner gradually decreasing towards the north-east corner (0 to $5 \%$ ). The time series started in 1998, and the data has been included in the German Small-scale Bottom Trawl Survey (GSBTS) (see Ehrich et al. 2007 for further information). Since that year, epifauna was sampled twice a year in January (1st quarter) and in July to August (3rd quarter) on board the fisheries research vessel (FRV) 'Walther Herwig'. Sampling did not take place in winter 1998 and 1999 due to ship time constraints.

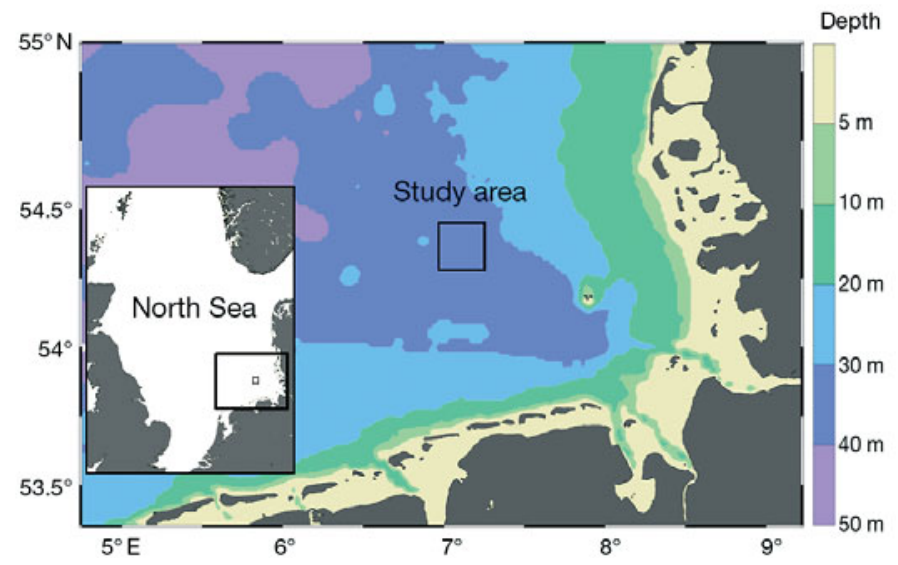

Fig. 1. Location and depth of the study area in the North Sea

\subsection{Beam trawl sampling}

Epifauna was sampled with a standardized $2 \mathrm{~m}$ beam trawl made of galvanized steel with a chain mat attached. The beam trawl was fitted with a $20 \mathrm{~mm}$ net and a cod end of $4 \mathrm{~mm}$ mesh size. A depth-finding sonar (Scanmar) was attached to the top of the net just behind the steel beam to determine the exact time and position of contact with the seabed. From the moment of contact with the seabed the beam was towed at a speed of about 1.5 to 2 knots for $5 \mathrm{~min}$. Altogether, 153 beam trawls were taken from 1998-2007. In general, 9 replicates were taken in each sampling season but the replicate number varied between 3 (winter 2000) and 13 (winter 2004) mainly due to adverse weather conditions. On average, 8.5 replicates were taken.

\subsection{Sample treatment}

Samples were sieved (5 $\mathrm{mm}$ mesh size) and epibenthic fauna were separated from the remains. The majority of species were identified on board. Unidentified species were preserved in a $4 \%$ seawater formalin solution for later identification in the laboratory. Abundances were counted and wet weights of the epifauna were determined using a motion-compensated marine scale (Pols) with an accuracy of $1 \mathrm{~g}$. Modular epifauna were recorded as present or absent and, if possible, weighed. All animals were identified to the lowest possible taxonomic level.

\subsection{Data analysis}

Sampled infauna species were excluded from the analysis because sampling gear was not appropriate for representative sampling of these species (Reiss et al. 2006a). Small epibenthic fishes such as Arnoglossus laterna, Buglossidium luteum and Pomatoschistus minutus were included. Abundance and biomass data were standardised to a tow length of $250 \mathrm{~m}$ (area sampled $=500 \mathrm{~m}^{2}$ ). Shannon-Wiener Index $H^{\prime}$ and species richness (total number of species) were calculated to assess diversity changes during the study period. Abundance, biomass and diversity measures were given as mean values for the corresponding year/season. Non-metric multidimensional scaling (nMDS) in the PRIMER v. 6 package (Plymouth Marine Laboratory) was used, based on untransformed and 4th root transformed abundance data. Both transformations were used in order to analyse the influence of only common species (untransformed) as well as rare species (4th root) on the similarities between years/seasons. Significance tests for temporal differences in 
community structure were performed using ANOSIM randomisation tests. Similarities were calculated using the Bray-Curtis coefficient. Species which were predominantly responsible for the dissimilarity between clusters were determined with the similarity percentage analysis (SIMPER) of PRIMER.

\subsection{Temperature data}

Epifauna sampling was supplemented by hydrographical measurements (CTD profiles) during the surveys. In general, 15 profiles were taken in each sampling season but the replicate number varied between 9 (summer 1999) and 22 (winter 2004). A total of 245 CTD profiles were taken from 1998-2007. Surface and bottom temperature during the sampling period were given as average temperature per year and season.

\section{RESULTS}

\subsection{Temperature}

Surface as well as bottom temperature varied considerably between winter and summer in the study area (Fig. 2). Bottom winter temperature ranged from $5.8^{\circ} \mathrm{C}$ (2000) to $8.9^{\circ} \mathrm{C}(2007)$, bottom summer temperature from $14.8^{\circ} \mathrm{C}(2006)$ to $18.1^{\circ} \mathrm{C}(2004)$. The water column was generally well-mixed in winter. Thus, winter surface temperatures ranged in the same magnitude as the winter bottom temperature $\left(5.7\right.$ to $\left.8.8^{\circ} \mathrm{C}\right)$. On the other hand, summer bottom and surface temperature were considerably different in the years 2002, 2003 and 2006. In these years, summer surface temperatures exceeded $19^{\circ} \mathrm{C}$. In summer 2006 the difference between surface and bottom temperature was $4.4^{\circ} \mathrm{C}$. Lowest summer surface temperature $\left(16.5^{\circ} \mathrm{C}\right)$ was recorded in 2005.

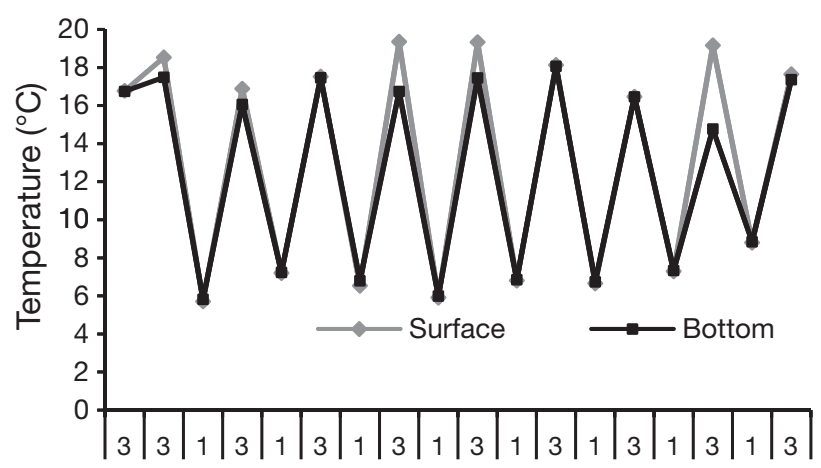

Fig. 2. Mean surface and bottom temperature $\left({ }^{\circ} \mathrm{C}\right)$ in the study area from summer 1998 to summer 2007. 1: winter; 3: summer

\subsection{Abundance, biomass and diversity}

The highest abundance was found in summer 1998 at the beginning of the study period, with 6195 ind. $500 \mathrm{~m}^{-2}$ (Fig. 3). It dropped by about half in the following season (summer 1999 and winter 2000) to 3090 and 2428 ind. $500 \mathrm{~m}^{-2}$, respectively. With the exception of summer 2001 (2736 ind. $500 \mathrm{~m}^{-2}$ ), abundance was considerably lower than in previous years, ranging between 187 ind. $500 \mathrm{~m}^{-2}$ (summer 2006) and 1168 ind. $500 \mathrm{~m}^{-2}$ (winter 2003).

Mean biomass was highest in summer 1998 with

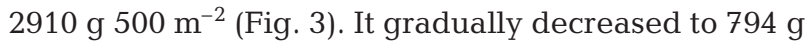
$500 \mathrm{~m}^{-2}$ until winter 2001. In the following summer

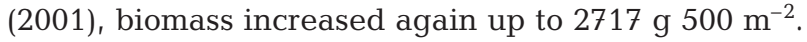
Between winter 2002 and summer 2007, biomass var-

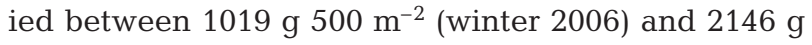
$500 \mathrm{~m}^{-2}$ (winter 2005).

In general, mean species number (species richness) and Shannon-Wiener index increased continuously during the study period (Fig. 4). Thus, lowest values of both parameters were found at the beginning of the

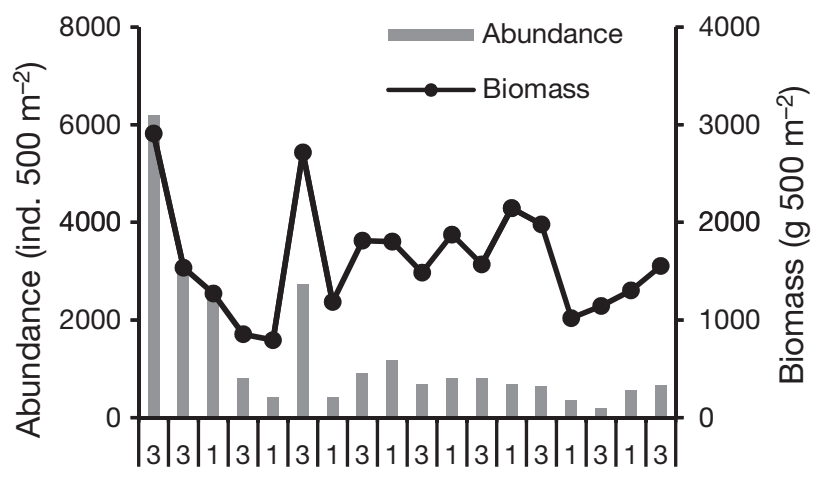

Fig. 3. Mean abundance (ind. $500 \mathrm{~m}^{-2}$ ) and biomass (g $500 \mathrm{~m}^{-2}$ ) in the study area from summer 1998 to summer 2007. 1: winter; 3: summer

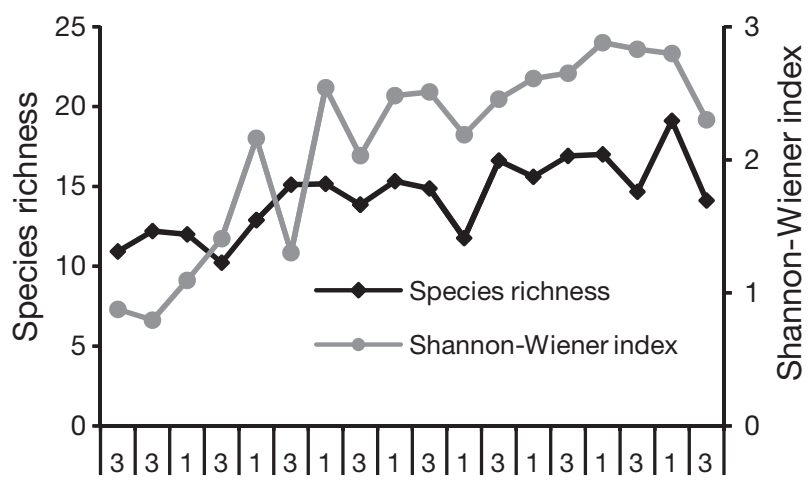

Fig. 4. Species richness and Shannon-Wiener index $\left(H^{\prime}\right)$ in the study area from summer 1998 to summer 2007. 1: winter; 3: summer 
study period, with 10 species in summer 2000 and the lowest Shannon-Wiener index (0.79) in summer 1999. In contrast, the highest species richness (19 species) was recorded in winter 2007 and highest Shannon Wiener index (2.88) in winter 2006.

\subsection{Species abundance and biomass}

In the beginning of the study period, the brittle star Ophiura albida was the most dominant species in terms of both abundance and biomass (Fig. 5). Highest values were recorded with 5037 ind. $500 \mathrm{~m}^{-2}$ and $1527 \mathrm{~g}$
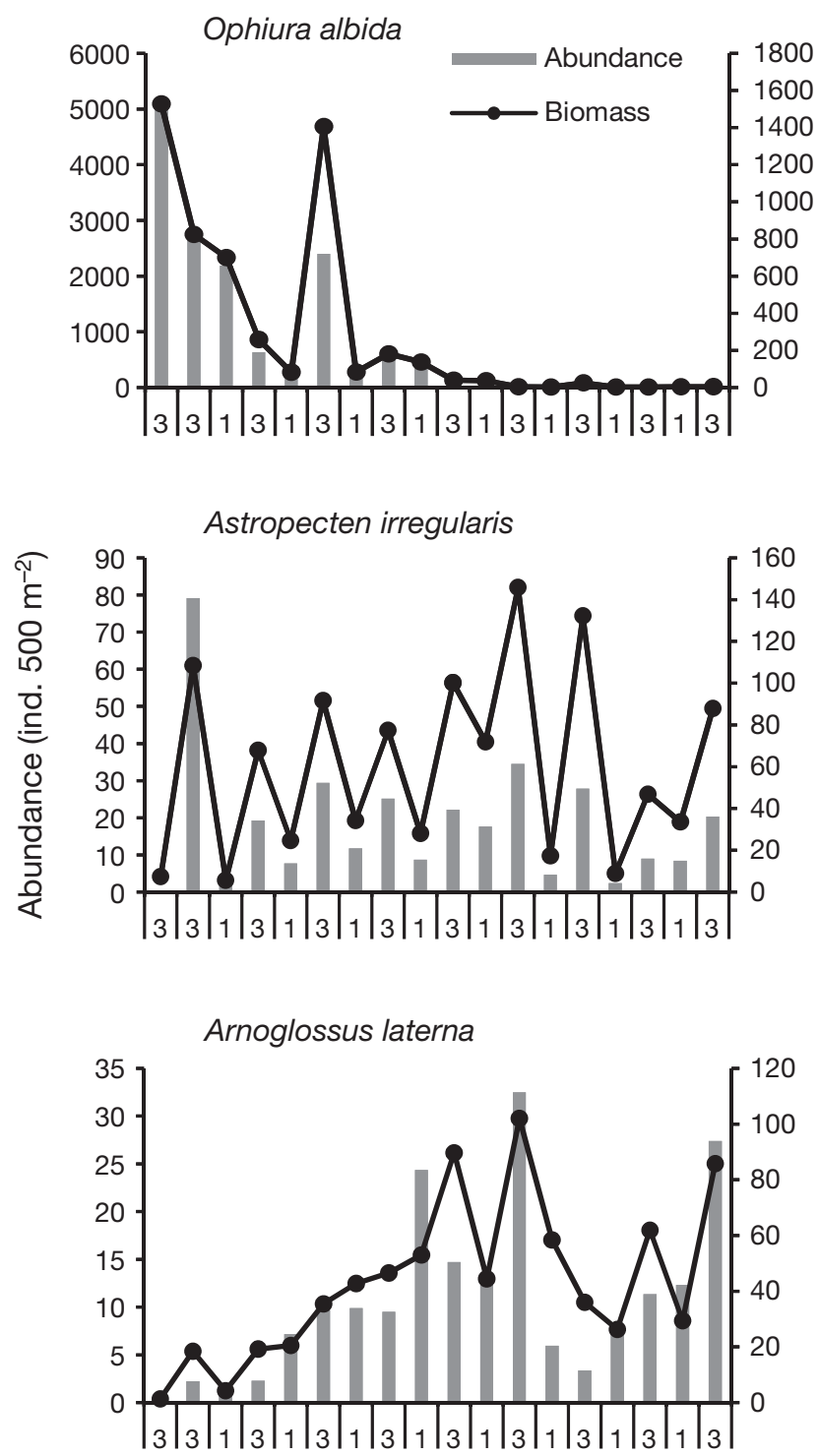

$500 \mathrm{~m}^{-2}$ in 1998. Abundance and biomass decreased continuously until winter 2001 with very low values of 246 ind. $500 \mathrm{~m}^{-2}$ and $82 \mathrm{~g} 500 \mathrm{~m}^{-2}$. O. albida reappeared with high abundance (2400 ind. $500 \mathrm{~m}^{-2}$ ) and biomass

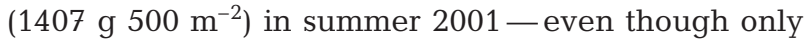
biomass attained the high 1998 values, while the abundance was only about half that of 1998 values - due to more adult individuals in summer 2001 compared to earlier years and season. After summer 2001, abundance and biomass of $O$. albida varied from 501 ind. $500 \mathrm{~m}^{-2}$ (summer 2002) to 5 ind. $500 \mathrm{~m}^{-2}$ (winter 2006)

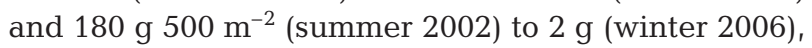
respectively.

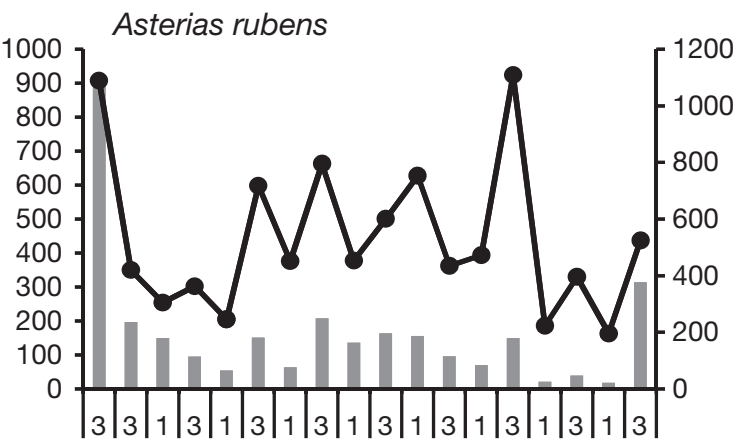

Buglossidium luteum
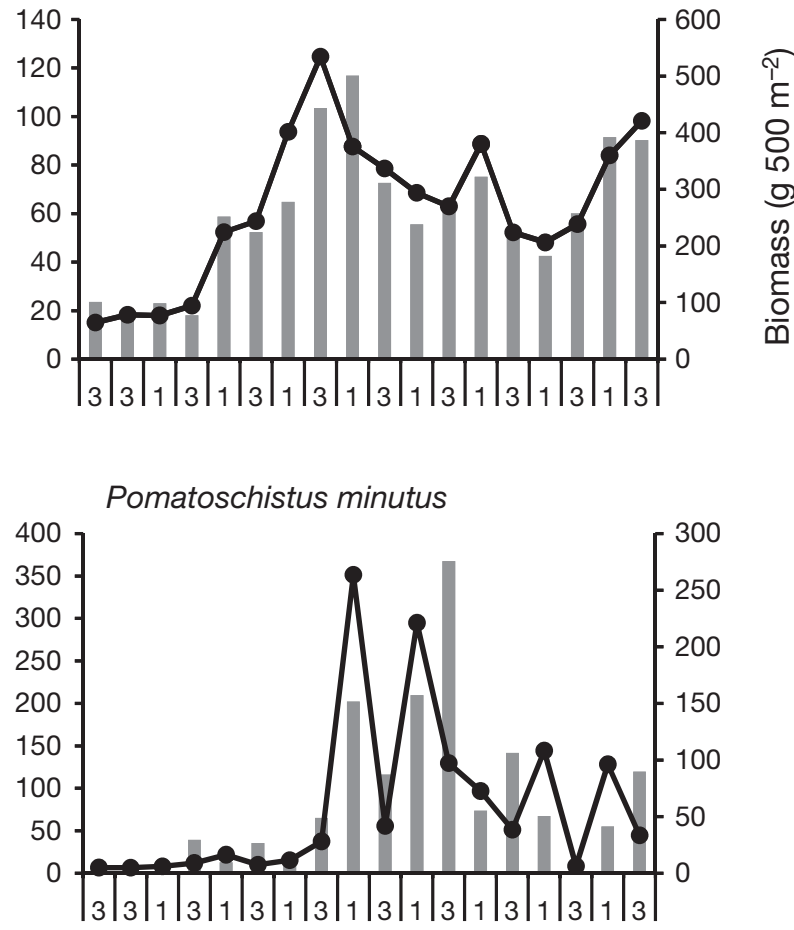

Fig. 5. Ophiura albida, Asterias rubens, Astropecten irregularis, Buglossidium luteum, Arnoglossus laterna and Pomatoschistus minutus. Mean abundance (ind. $500 \mathrm{~m}^{-2}$ ) and biomass $\left(\mathrm{g} 500 \mathrm{~m}^{-2}\right)$ in the study area from summer 1998 to summer 2007. 1: winter; 
Highest abundances of the seastars Asterias rubens and Astropecten irregularis were also recorded at the beginning of the study period (Fig. 5). A. rubens attained its highest abundance in summer 1998 (898 ind. $500 \mathrm{~m}^{-2}$ ), and A. irregularis in summer 1999 (79 ind. $500 \mathrm{~m}^{-2}$ ); while the highest biomass was recorded in

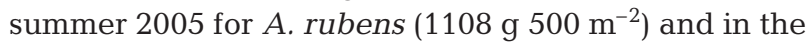
summers of 2004 and 2005 for A. irregularis (146 g

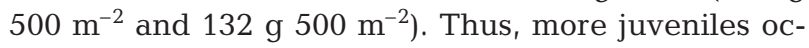
curred in 1998-1999 in contrast to more adults in 2004-2005. Additionally, a seasonal pattern in abundance and biomass was obvious for $A$. irregularis, with higher values in summer and lower values in winter.

In contrast to Ophiura albida, Asterias rubens and Astropecten irregularis, abundance and biomass of other species were generally low in the beginning of the study period (Figs. 5 \& 6). Buglossidium luteum and Arnoglossus laterna were the first species to conspicuously increase in abundance; both species more than 3-fold between summer 2000 and winter 2001. In the following season, abundance as well as biomass increased continuously to mean peak values of 117 ind.

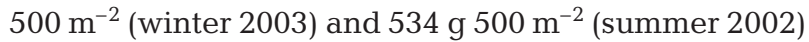

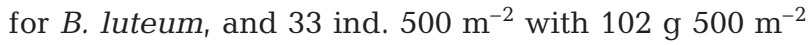
for A. laterna (summer 2004). Additionally, the small gobies Pomatoschistus minutus occurred in higher abundance from winter 2003. The highest abundance

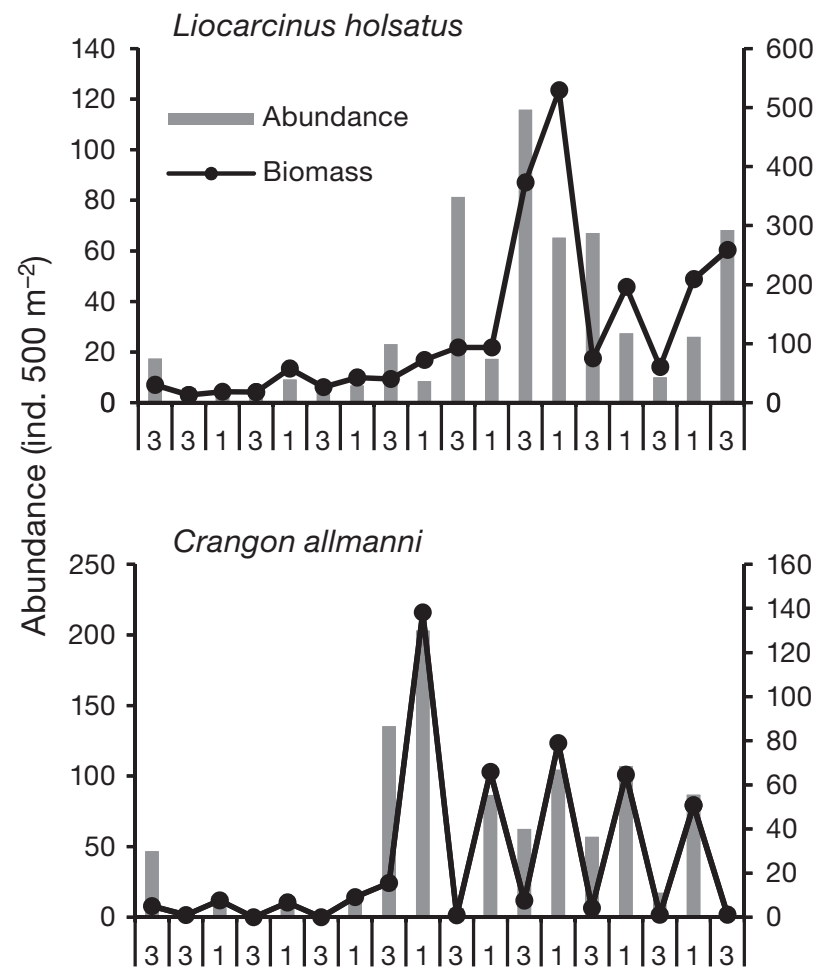

of $P$. minutus was recorded in summer 2004 (368 ind. $500 \mathrm{~m}^{-2}$ ), and high biomasses were recorded in winter

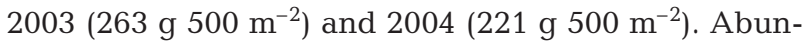
dance as well as biomass of B. luteum, A. laterna and $P$. minutus was highly variable, but again were not as low as in the first 3 to 4 seasons of the study period.

Abundance of the swimming crab Liocarcinus holsatus increased suddenly in summer 2003 (Fig. 6). Similar to Arnoglossus laterna and Pomatoschistus minutus, the highest abundance of $L$. holsatus was found in summer 2004 (116 ind. $500 \mathrm{~m}^{-2}$ ), and the highest bio-

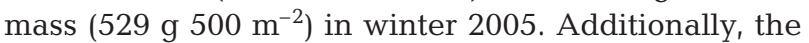
abundance:biomass ratios revealed a large number of juvenile individuals in summer 2004 (and summer 2003), very similar to A. laterna and $P$. minutus.

The highest abundance and biomass of Crangon crangon and C. allmanni were recorded in winter 2004

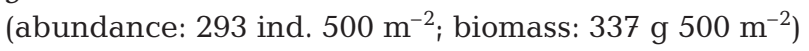
and winter 2003 (203 ind. $500 \mathrm{~m}^{-2}$; 138 g $500 \mathrm{~m}^{-2}$ ), respectively. Both species revealed a strong seasonal pattern with higher abundances and biomasses in the winter season. An opposing seasonal pattern — as well as slightly higher levels of abundance and biomass over the study period - was observed for the masked crab Corystes cassivelaunus (Fig. 6). Its highest abundance and biomass were recorded in summer 2005, with max-

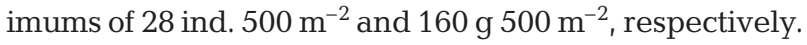
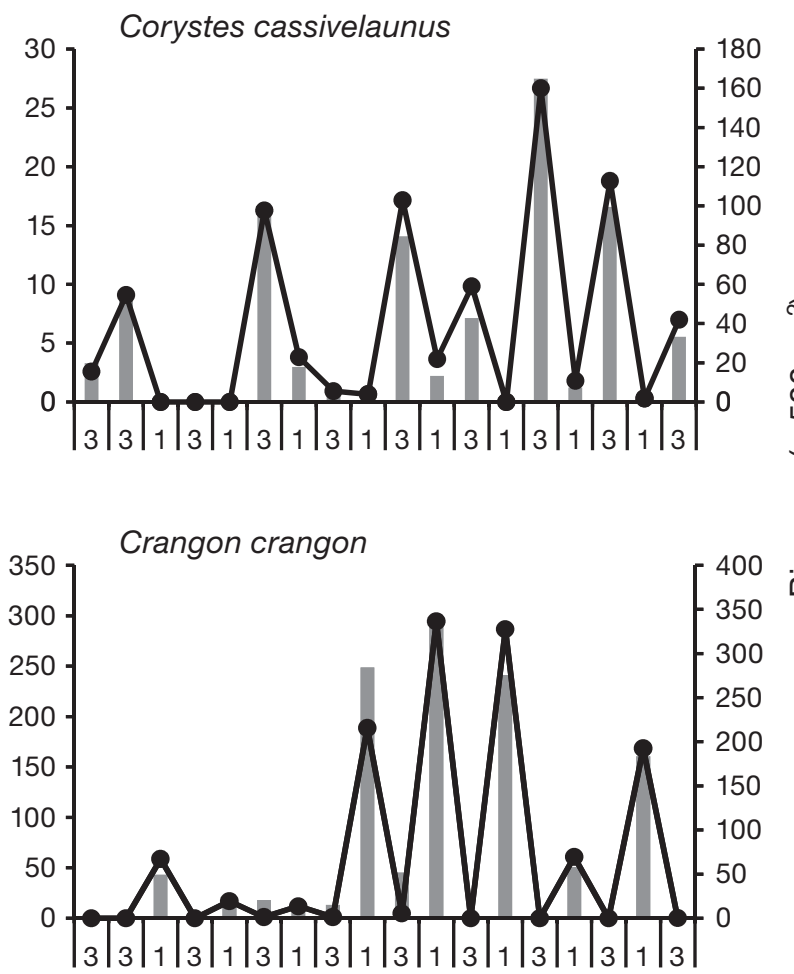

Fig. 6. Liocarcinus holsatus, Corystes cassivelaunus, Crangon allmanni and Crangon crangon. Mean abundance (ind. $500 \mathrm{~m}^{-2}$ ) and biomass $\left(\mathrm{g} 500 \mathrm{~m}^{-2}\right)$ in the study area from summer 1998 to summer 2007. 1: winter; 3: summer 

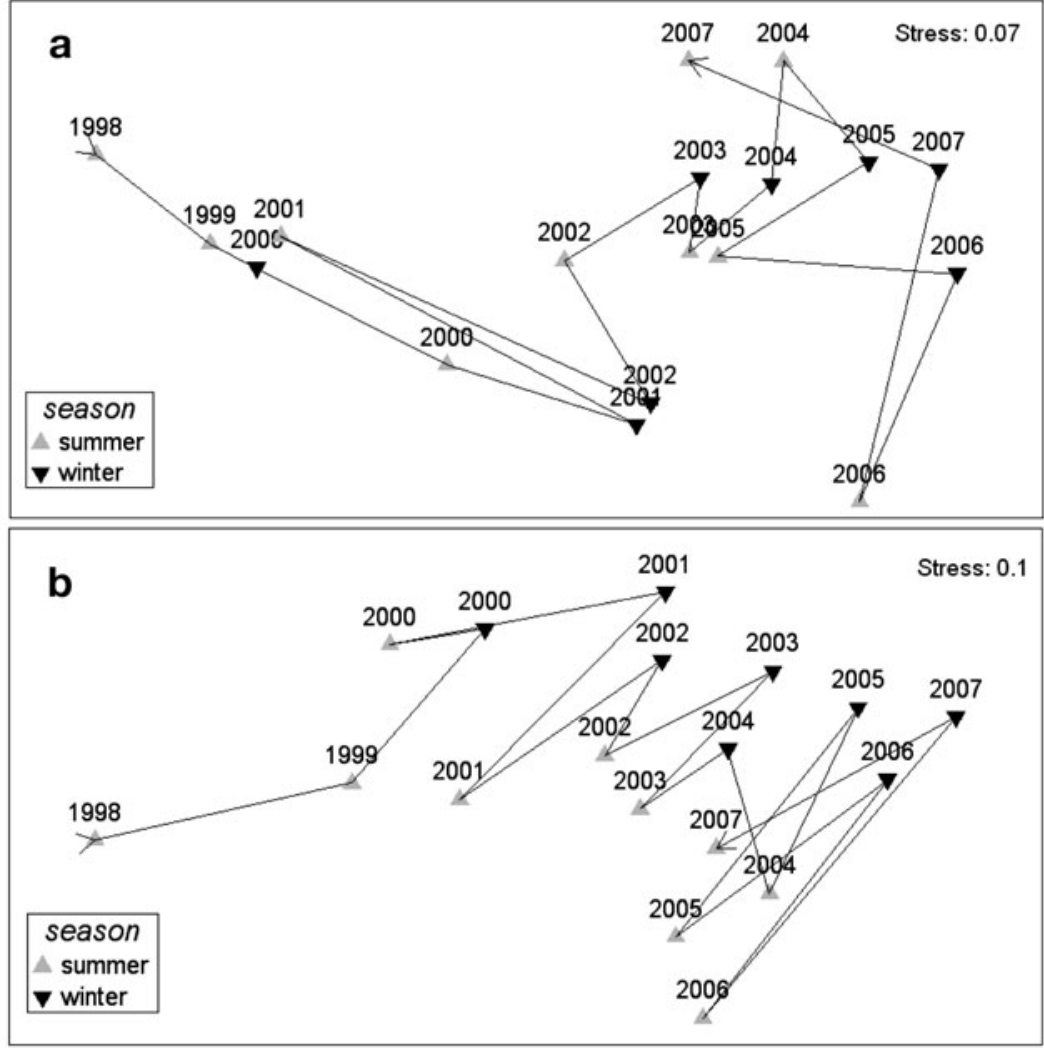

Fig. 7. Non-metric multidimensional scaling (nMDS) plots based on (a) untransformed abundance data and (b) 4th root transformed abundance data of the communities in the study area from summer 1998 to summer 2007

Table 1. Mean abundance (ind. $500 \mathrm{~m}^{-2}$ ) of 7 dominant species from 1998 to 2002 (winter) and 2002 (summer) to 2007 with their contribution to the dissimilarity (\%) between the periods

\begin{tabular}{|c|c|c|c|}
\hline \multirow[t]{2}{*}{ Taxon } & \multicolumn{2}{|c|}{$\longrightarrow$ Abundance } & \multirow{2}{*}{$\begin{array}{c}\text { Contribution } \\
\text { to dissimilarity } \\
(\%)\end{array}$} \\
\hline & $\begin{array}{l}002 \text { (winter) } \\
500 \mathrm{~m}^{-2} \text { ) }\end{array}$ & $\begin{array}{l}2002 \text { (summer)-2007 } \\
\text { (ind. } 500 \mathrm{~m}^{-2} \text { ) }\end{array}$ & \\
\hline Ophiura albida & 1914 & 89 & 67 \\
\hline Asterias rubens & 230 & 125 & 7 \\
\hline $\begin{array}{l}\text { Pomatoschistus } \\
\text { minutus }\end{array}$ & 17 & 119 & 7 \\
\hline Crangon crangon & 11 & 93 & 6 \\
\hline Crangon allmanni & 11 & 66 & 4 \\
\hline Liocarcinus holsatus & 7 & 46 & 3 \\
\hline Buglossidium luteum & 37 & 74 & 2 \\
\hline Total & & & 95 \\
\hline
\end{tabular}

\subsection{Community structure}

Fig. 7 provides the nMDS analyses based on untransformed abundance data and 4th root transformed abundance data. Fig. 7a reveals a significant community shift in the year 2002 expressed by the high dissimilarity $(75 \%)$ of the communities in the years 1998 to 2002 (winter) and 2002 (summer) to 2007 (ANOSIM,
$\mathrm{R}=0.665, \mathrm{p}<0.001)$. The decreasing abundance of Ophiura albida was mainly responsible for this community shift (67\%; Table 1). In combination with changes in abundance of Asterias rubens (7\%), Pomatoschistus minutus (7\%), Crangon crangon (6\%), C. allmanni (4\%), Liocarcinus holsatus (3\%) and Buglossidium luteum (2\%), the brittle star O. albida contribute $95 \%$ to the dissimilarity in the community structure (Table 1).

The nMDS analyses based on 4th root transformed abundance data show distinct seasonal differences in the community structure from 2001 to 2007 (30\%; Fig. 7b) (ANOSIM, R = 0.512, $\mathrm{p}=0.001$ ). These differences resulted mainly from the seasonal patterns in abundance of species such as Crangon crangon, C. allmanni, Corystes cassivelaunus, Pomatoschistus minutus, Asterias rubens and Liocarcinus holsatus. These species contribute $43 \%$ to the seasonal dissimilarity in community structure from 2001 to 2007 (Table 2).

\section{DISCUSSION}

The regime shift occurring in the North Sea starting ca. 1988 was characterised by a period of mild winters, which were linked to a phase of continuously increasing NAOI (see Section 1). A number of simultaneous physical and biological changes ca. 1988 in the North Sea, the Baltic Sea and broadly over the Atlantic have since been considered as a regime shift (Reid et al. 2001, Beaugrand 2004, Alheit et al. 2005, Reid 2005). Beaugrand (2004) hypothesised that the regime shift in the North Sea resulted from the conjunction of 3 main features: (1) a change in local hydroclimatic forcing; (2) a displacement of oceanic biogeographical boundaries to the west of the European shelf; and (3) an increase in oceanic inflow into the North Sea.

Regional hydro-climatic parameters such as wind intensity/direction and SST are strongly related to the NAOI (Dippner 1997a, Reid et al. 1998). Thus, the period after the regime shift was characterised by continuously increasing NAOI in conjunction with increasing SST. Beare et al. (2002) found an increase in 
Table 2. Mean abundance (ind. $500 \mathrm{~m}^{-2}$ ) of 7 dominant species in winter and summer with their contribution to the dissimilarity (\%) between the seasons

\begin{tabular}{|c|c|c|c|}
\hline \multirow[t]{2}{*}{ Taxon } & \multicolumn{2}{|c|}{$\longrightarrow$ Abundance -} & \multirow{2}{*}{$\begin{array}{c}\text { Contribution } \\
\text { to dissimilarity } \\
(\%)\end{array}$} \\
\hline & $\begin{array}{c}\text { Winter } \\
\text { (ind. } 500 \mathrm{~m}^{-2} \text { ) }\end{array}$ & $\begin{array}{c}\text { Summer } \\
\text { (ind. } 500 \mathrm{~m}^{-2} \text { ) }\end{array}$ & \\
\hline Crangon crangon & 142 & 9 & 10 \\
\hline Processa spp. & 19 & 0 & 8 \\
\hline Crangon allmanni & 85 & 22 & 7 \\
\hline Corystes cassivelaunus & 1 & 13 & 6 \\
\hline Pomatoschistus minutus & 75 & 121 & 5 \\
\hline Asterias rubens & 74 & 160 & 4 \\
\hline Liocarcinus holsatus & 22 & 53 & 4 \\
\hline Total & & & 43 \\
\hline
\end{tabular}

1998, continuing the recovery from the cold winter and following the reversal of the NAOI during the preceding winter (ICES 1999). The most prominent development at the beginning of our study period was the outbreak of Ophiura albida, followed by the continuously decreasing abundance of this brittle star from 1998 to 2007, resulting in a community shift in 2002. In the sandy and muddy areas of the German Bight up to $40 \mathrm{~m}$ depth, O. albida represents a characteristic element of the epibenthos and contributes significantly to total abundance and biomass (Dahm

late winter temperature (January, February) of $\sim 1.1^{\circ} \mathrm{C}$ in the German Bight between the early 1950s and the late 1990s, which is in line with the warming trend of the North Sea observed by Edwards et al. (2002). This warming trend is reflected in the temperature data of the present study by a general increase in winter bottom and surface temperature over the study period. However, the general warming trend was interrupted by the severe winter of 1995-1996 associated with an extreme negative NAOI (-3.78), which, from one year to the next, flipped from being one of the most positive values to the most negative value in this century (ICES 1999). At a station close to the study area, Reiss et al. (2006b) found a mean SST in March 1996 of $3.4^{\circ} \mathrm{C}$ below the long-term average (1973-1993). Also, in the following winter $(1996-1997$; NAOI $=-0.17)$ the mean SST was up to $2{ }^{\circ} \mathrm{C}$ below this long-term mean in and around the study area (Reiss et al. 2006b), indicating a slow recovery of temperature from the cool event in 1995-1996, following a slightly higher NAOI.

\subsection{Effects of the severe winter}

Generally, severe winters enhance winter mortality, and reduce reproduction and production (often dramatically), resulting in a decrease in species number, abundance and biomass. For example, Beukema (1992) found that one third of infaunal species on tidal flats in the Dutch Wadden Sea died during cold conditions, and macrofaunal communities of the Northumberland coast revealed reduced diversity and increased survival of dominant species after severe winters (Buchanan \& Moore 1986). Additionally, the period after severe winters is characterised by a highly successful recruitment of r-selective opportunistic species (Ziegelmeier 1970, Kröncke et al. 1998, Schröder 2005).

We started our epifauna series in summer 1998, about $2 \mathrm{yr}$ after the severe winter of 1995-1996. The temperatures in the southern North Sea increased in
1993, Callaway et al. 2002). The sediment preference of $O$. albida in the German Bight is not yet known. Tyler \& Banner (1977) found a correlation between fine sediments and the distribution of $O$. albida in the Bristol channel and these both correlated with the energy distribution of the hydrodynamic regime. They concluded that the settlement of both fine sediment and newly metamorphosed larvae of $O$. albida have the same sedimentation rate. However, no similar results for the German Bight have yet been published, but the main distribution areas of $O$. albida in the extended German Bight correspond with areas of high sedimentation rates and unique hydrodynamic regimes (Frisian frontal area and westerlies of Helgoland) (H. Neumann unpubl. data).

Data on the temporal variability of Ophiura albida are sparse. Reiss \& Kröncke (2004) studied the seasonal variability of an epibenthic community south of the study area between November 2000 and May 2002. They found very high abundance of $O$. albida in the summer months and low values in the winter months, which largely correspond with our data in the same period. During oxygen deficiency in the early 1980s, O. albida was found near the Danish west coast and in the southeastern German Bight (Dethlefsen \& von Westernhagen 1983, Dyer et al. 1983, Niermann et al. 1990). In both areas, O. albida revealed higher mortality during 19821983 under oxygen deficiency, but also a fast recovery and high abundances under normal oxygen conditions in 1984-1985, probably due to its general high tolerance to low oxygen (Vistisen \& Vismann 1997) and its r-selected life history (Dahm 1993). In addition to its high tolerance to low oxygen and temperature (Ursin 1960) $O$. albida is small in size (adults $=9 \mathrm{~mm}$ ), short-lived ( 3 to 9 yr), fast-growing and revealed a high productivity per year (Dahm 1993). Thus, O. albida is a typical r-selected opportunist and able to recolonise a habitat faster than other species after 'catastrophic' events.

Similar to the patterns following oxygen deficiency, $O$. albida showed very high abundances after the severe 
winter 1995-1996 in the study area. This indicates, that (1) the mortality of $O$. albida was low during the severe winter due to its high tolerance to low temperature (Ursin 1960) and (2) the high abundances of O. albidaand thus low diversity at the beginning of our studywere a direct effect of the severe 1995-1996 winter.

Similar patterns after severe winters were found for benthic infauna by Kröncke et al. (1998), who found rselective polychaetes such as Spiophanes bombyx and Scoloplos armiger favoured by cold conditions in the sublittoral zone off Norderney. This was also found by Schröder (2005) in the German Bight close to the study area, and their results confirmed those of Ziegelmeier (1970), who observed unusual high abundances of $S$. bombyx after the severe winter of 1963-1964 near the island of Sylt. Ziegelmeier (1970) explained the high abundances of $S$. bombyx with the absence of the mussel Fabulina fabula (which feed on polychaete larvae) after cold winters. The absence of predators on $O$. albida larvae and post larvae due to cold winter temperatures could additionally be responsible for high abundance of the ophiurid in our study. Reproduction of $O$. albida is a well defined annual cycle: initiation of gametogenesis between October and December; first spawning in late May and early June; and spent adults and planktonic larvae up to early October (Tyler 1977). Thus, the absence of predators on larvae and post larvae of $O$. albida in October 1995 could have resulted in high recruitment success in 1996, which was confirmed by I. Kröncke et al. (unpubl) in the sublittoral zone off Norderney. They found an unusually high abundance of juvenile ophiurids (1240 ind. $\mathrm{m}^{-2}$ ) in the $630 \mu \mathrm{m}$ sieve remains in summer 1996, confirming our hypothesis and indicating a successful large-scale recruitment of this species in the German Bight.

\subsection{Recovery after the severe winter}

The general temporal pattern in the study area after the outbreak of Ophiura albida showed the decrease of the ophiurid parallel to the increase in the abundance and biomass of other species (e.g. Buglossidium luteum, Arnoglossus laterna, Liocarcinus holsatus), resulting in a community shift in summer 2002. Additionally, diversity (Shannon-Wiener Index and species richness) increased, and species such as Astropecten irregularis, Corystes cassivelaunus and the Crangonidae revealed distinct seasonal patterns, clearly reflected in the results of the nMDS analysis (based on 4th root transformed data). All these patterns, beginning with the outbreak of $O$. albida, were characteristic succession stages of a developing benthic community after a catastrophic event (Arntz \& Rumohr 1982). Arntz \& Rumohr (1982) suggest the occurrence of seasonal variability in particular forms a decisive part of 'stability' in benthic communities after a 'catastrophe' in temperate areas with a highly dynamic physical regime. A distinct seasonal pattern after the community shift observed in this study is apparent for the shrimps Crangon crangon and C. allmanni (with high abundance and biomass in winter) and for C. cassivelaunus and A. irregularis (with high abundance and biomass in summer). C. crangon migrates offshore during autumn, from the Wadden Sea towards the German Bight, and migrates back towards nearshore coastal areas in early spring (Boddeke 1976, Reiss \& Kröncke 2004). An inverse migration pattern with inshore migration during winter and offshore migration during summer was found by Allen (1960) for C. allmanni on the Northumberland coast. In contrast, Creutzberg \& van Leeuwen (1980) detected no migration pattern for $C$. allmanni in the southwestern North Sea, and attributed abundance changes to mortality in summer. This is supported by Blahudka \& Türkay (2002), who found the only reproducing population of C. allmanni in the Helgoland Trench (German Bight). They also hypothesised a link between the higher winter abundance and currents and water masses. Thus, we assume that $C$. allmanni in the study area originate from the Helgoland Trench and that the seasonal variability is caused by summer mortality and hydrodynamic changes, and not by migration. The seasonal variability of $C$. cassivelaunus in the study area reflects its reproductive cycle, since this species spends much of the time buried in sediment, which it only leaves during the breeding season in summer (Hartnoll 1972, Reiss \& Kröncke 2004). Freeman et al. (2001) found that $A$. irregularis migrates to deeper water in winter to avoid low temperatures and stormy conditions.

The severe winter in 1995-1996 was a climatetriggered catastrophic event comparable to anthropogenic events such as pollution or dredging. Especially in a shallow, well mixed region such as the German Bight, the effects of climate variability were strongly linked to temperature, not only in severe winters but also in mild periods. Temperature and food supply are regarded as the main structuring factor for benthic communities at a temporal scale (Clark \& Frid 2001, Kröncke et al. 2004). As described above, a continuous recovery towards positive NAOI values from 1996 to 2000 was clear, indicated, in particular, by the resumption of many of the ocean-climate features associated with that positive phase (ICES 2000). In the winter preceding 2001, the NAOI again became negative, but the strong effect seen during the 1996 switch was not observed (ICES 2002). The NAOI for the period 2002 to 2006 was in neutral or weak mode (-1.89 to 2.8$)$ and did not have a strong influence on oceanic variability (ICES $2004,2005,2006,2007)$. However, the trend from 1996- 
2006 has been a combined effect of warming together with a significant increase in length of the warming season in the southern North Sea (ICES 2007), which is reflected in an increasing trend in winter bottom temperature in the study area $\left(\sim 3^{\circ} \mathrm{C}, 1998-2007\right.$; Fig. 2). The seasonal cooling of the North Sea usually began in mid-August, but the area-averaged SST in September $2002\left(16.2^{\circ} \mathrm{C}\right)$ was the highest since 1971 . Also, SST in the winter and spring months of 2002 was above normal, and much of the cooling that usually takes place in February and March did not occur (ICES 2003). Areaaveraged SST for August $2003\left(>18^{\circ} \mathrm{C}\right)$ revealed the highest value since 1968, and for August 2004 the second highest (ICES 2004, 2005). In October and November 2005, SST was the highest it had been since 1971, resulting in SSTs that were $2^{\circ} \mathrm{C}$ warmer than normal in autumn/winter (ICES 2006). The autumn 2005 SST was then exceeded in October 2006; this SST value was $2.4^{\circ} \mathrm{C}$ above the climatological mean (1971-1993), and the SST of December of the same year was $1.7^{\circ} \mathrm{C}$ above the climatological mean. These extreme values, in conjunction with the general warming of the North Sea, resulted (for several years) in vegetation periods (i.e. periods of primary production) that were considerably longer than normal (ICES 2007).

In general, mortality is lower and reproduction higher during mild winters in comparison to cold winters. Also primary production starts earlier in mild years, and may last the whole year, which could result in a higher food supply for benthic fauna (Kröncke et al. 1998, Reid et al. 1998). Additionally, according to Beukema (1992), benthic communities are more affected by biological interactions (such as predation) after mild winters. Thus, high abundance and biomass of many species after the community shift in 2002 (e.g. Liocarcinus holsatus, Pomatoschistus minutus, Crangon allmanni, C. crangon) could be attributed to enhanced primary production due to increased insolation, which leads to higher food supply for epibenthic fauna. This was supported not only by the general warming trend, but also - and in particular - by the exceptionally warm autumn SSTs. Species, which benefitted from this higher food supply and increased in abundance were also potential predators on Ophiura albida, such as the flatfishes Buglossidium luteum and Arnoglossus laterna. Both species have a varied diet that includes polychaetes, crustaceans and echinoderms (Nottage \& Perkins 1983, Darnaude et al. 2001). Nottage \& Perkins (1983) observed that the solenette B. luteum consumes any item which falls within the size range that it finds manageable. One might assume a high predation pressure of these 2 predators on O. albida, since high predator abundance and biomass correspond with low prey abundance and biomass. P. minutus and L. holsatus might also feed on $O$. albida because both are general- ists, feeding on any organism of appropriate size and texture (Choy 1986, Aarnio \& Bonsdorff 1993). This is supported by Fonds (1973), who found an increase of $P$. minutus following the severe winter of 1962-1963, which he posited was due to an increase in food supply. Additionally, Aronson (1989) found that swimming crabs such as L. holsatus and Asterias rubens, which both increased in abundance in the study area, feed intensively on brittle stars in British waters.

Furthermore, temperature directly influences key stages of reproduction, such as gametogenesis and spawning, with pronounced effects on recruitment. Species such as Liocarcinus holsatus, Arnoglossus laterna or Pomatoschistus minutus revealed higher recruitment success in the period from 2002 to 2004, which might be related to the higher food supply (see previous paragraph) and/or the direct influence of temperature on reproduction. For example, the larval development (from hatching to metamorphosis) of $L$. holsatus is faster with increasing temperature (Choy 1991). Larvae of the sea urchin Echinocardium cordatum (Kirby et al. 2007), as well as of many decapod crustacean larvae (Lindley et al. 1993), were found in the plankton in higher abundances and/or earlier due to temperature-induced shifts in the reproduction cycle. This is supported by Greve et al. (2001), who found that temperature modifies the beginning, end, length and intensity of the seasonality of zooplankton populations (including meroplankton). Dippner $(1997 a, b)$ found that climate variability delays the spawning time of fish by up to 2 mo in near-coastal areas, and that recruitment variability of western mackerel and the 3 gadoids (North Sea cod, saithe and whiting) was highly correlated with the variability of North Sea SSTs. Thus, the high recruitment success of species such as L. holsatus between 2002 and 2004 might be related to direct positive effects of temperature on the reproduction cycle of this species.

Another explanation might be that the increasing temperatures influence the migration patterns of species, since migration is triggered mostly by changes in temperature (see above, this section). Thus, the increase in abundance of migrating species such as Liocarcinus holsatus, Crangon crangon or Pomatoschistus minutus since 2002-2003 might be a result of the absence of migration due to increased temperature in the German Bight especially in winter.

Salinity is considered to be a major factor that influences plankton communities in the North Sea (e.g. Edwards et al. 2002). Beare et al. (2002) reported a long-term freshening of the eastern North Sea and a long-term increase in salinity of the western North Sea. In the German Bight, salinity is largely influenced by runoff from continental rivers, and varied largely over time and space (Becker et al. 1992). During our 
study period, extreme low salinities in the German Bight were found in 2001, persisting during the first half of 2002 (ICES 2003). However, these low salinities have had no obvious effects on epifauna, probably due to the ability of epifaunal species to adapt to the large variability in salinity in the German Bight.

Beare et al. (2002) also found a decrease in stratification east of ca. $5^{\circ} \mathrm{E}$, and an increase in Atlantic inflow via the English Channel. Both factors were strongly correlated with the NAOI, and have a major effect on the variability of zooplankton communities in the North Sea (Ottersen et al. 2001, Beare et al. 2002, Reid et al. 2003). Reid et al. (2003) reported that Atlantic inflow contributes $>90 \%$ of the nutrient input into the North Sea. Thus, we cannot exclude synergistic positive effects of Atlantic inflow and temperature on primary production. However, most of the variability in zooplankton communities was related to inflow via the northern entrance of the North Sea, which was less important for the German Bight than the inflow via the English Channel or the Baltic outflow. Furthermore, thermohaline stratification (Fig. 2) revealed no obvious changes over the study period. Generally, the German Bight is unstratified in winter, and only weakly stratified (or not stratified at all) in summer (Otto et al. 1990). This is confirmed by temperature profiles from the present study, revealing a well mixed water column in the study area from 1998 to 2007, with the exception of weak stratification in the summers of 2002, 2003 and 2006 (Fig. 2). This appears to contradict the long-term trend by Beare et al. (2002), but has had no ecological effects, according to our results. Thus, we conclude that temperature (at a decadal time scale) is the dominant factor influencing the temporal variability of epifaunal communities in the German Bight.

Acknowledgements. We thank the captains and crews of FRV 'Walther Herwig III' for their help with sampling. We are grateful to the Federal Research Centre for Fisheries (Hamburg) for providing ship time and data. The data analysis was funded by the EWE-Foundation (Oldenburg), which is kindly acknowledged.

\section{LITERATURE CITED}

Aarnio K, Bonsdorff E (1993) Seasonal variation in abundance and diet of the sand goby Pomatoschistus minutus (Pallas) in a northern Baltic archipelago. Ophelia 37:19-30

Alheit J, Möllmann C, Dutz J, Kornilovs G, Loewe P, Mohrholz V, Wasmund N (2005) Synchronous ecological regime shifts in the central Baltic and the North Sea in the late 1980s. ICES J Mar Sci 62:1205-1215

Allen JA (1960) On the biology of Crangon allmanni Kinahan in Northumberland waters. J Mar Biol Assoc UK 39:481-508

> Arntz WE, Rumohr H (1982) An experimental study of macrobenthic colonization and succession, and the importance of seasonal variation in temperate latitudes. J Exp Mar Biol Ecol 64:17-45
Aronson RB (1989) Brittlestar beds: low-predation anachronisms in the British Isles. Ecology 70:856-865

Beare DJ, Batten S, Edwards M, Reid DG (2002) Prevalence of boreal Atlantic, temperate Atlantic and neritic zooplankton in the North Sea between 1958 and 1998 in relation to temperature, salinity, stratification intensity and Atlantic inflow. J Sea Res 48:29-49

> Beaugrand G (2004) The North Sea regime shift: evidence, causes, mechanisms and consequences. Prog Oceanogr 60: $245-262$

> Becker GA, Dick S, Dippner JW (1992) Hydrography of the German Bight. Mar Ecol Prog Ser 91:9-18

Beukema JJ (1992) Expected changes in the Wadden sea benthos in a warmer world: lessons from periods with mild winters. Neth J Sea Res 30:73-79

> Blahudka S, Türkay M (2002) A population study of the shrimp Crangon allmanni in the German Bight. Helgol Mar Res 56:190-197

Boddeke R (1976) The seasonal migration of the brown shrimp Crangon crangon. Neth J Sea Res 10:103-130

Buchanan JB, Moore DC (1986) Long-term studies at a benthic station off the coast of Northumberland. Hydrobiologia 142:121-127

Callaway R, Alsvag J, de Boois I, Cotter J and others (2002) Diversity and community structure of epibenthic invertebrates and fish in the North Sea. ICES J Mar Sci 59: 1199-1214

Choy SC (1986) Natural diet and feeding habits of the crabs Liocarcinus puber and L. holsatus (Decapoda, Brachyura, Portunidae). Mar Ecol Prog Ser 31:87-99

> Choy SC (1991) Embryonic and larval biology of Liocarcinus holsatus and Necora puber (Crustacea: Brachyura: Portunidae). J Exp Mar Biol Ecol 148:77-92

Clark RA, Frid CLJ (2001) Long-term changes in the North Sea ecosystem. Environ Rev 9:131-187

Creutzberg F, van Leeuwen F (1980) The life cycle of Crangon allmanni kinahan in the southern North Sea. ICES CM 1980/L71

> Dahm C (1993) Growth, production and ecological significance of Ophiura albida and O. ophiura (Echinodermata: Ophiuroidea) in the German Bight. Mar Biol 116:431-437

Darnaude AM, Harmelin-Vivien ML, Salen-Picard C (2001) Food partitioning among flatfish (Pisces: pleuronectiforms) juveniles in a Mediterranean coastal shallow sandy area. J Mar Biol Assoc UK 81:119-127

Dethlefsen V, von Westernhagen H (1983) Oxygen deficiency and effects on bottom fauna in the eastern German Bight 1982. Ber Dtsch Wiss Komm Meeresforsch 30:43-53

> Dippner JW (1997a) Recruitment success of different fish stocks in the North Sea in relation to climate variability. Dtsch Hydrogr Z 49:277-293

> Dippner JW (1997b) SST Anomalies in the North Sea in relation to the North Atlantic Oscillation and the influence on the theoretical spawning time of fish. Dtsch Hydrogr Z 49: 267-275

Dyer MF, Pope JG, Fry PD, Law RJ, Portman JE (1983) Changes in fish and benthos catches off the Danish coast in September 1981. J Mar Biol Assoc UK 63:767-775

> Edwards M, Beaugrand G, Reid PC, Rowden AA, Jones MB (2002) Ocean climate anomalies and the ecology of the North Sea. Mar Ecol Prog Ser 239:1-10

Ehrich S, Adlerstein S, Brockmann U, Floeter J and others (2007) 20 years of the German Small-Scale Bottom Trawl Survey (GSBTS): a review. Senckenb Marit 37:13-82

Fonds M (1973) Sand gobies in the Dutch Wadden Sea (Pomatoschistus, Gobiidae, Pisces). Neth J Sea Res 6: $417-478$ 
Freeman SM, Richardson CA, Seed R (2001) Seasonal abundance, spatial distribution, spawning and growth of Astropecten irregularis (Echinodermata: Asteroidea). Estuar Coast Shelf Sci 53:39-49

Greve W, Lange U, Reiners F, Nast J (2001) Predicting the seasonality of North Sea zooplankton. Senckenb Marit 31: 263-268

Hartnoll RG (1972) The biology of the burrowing crab, Corystes cassivelaunus. Bijdr Dierkd 42:139-155

Hurrell JW (1995) Decadal trends in the North Atlantic Oscillation: regional temperatures and precipitation. Science 269:676-679

ICES (International Council for the Exploration of the Sea) (1999) The annual ICES ocean climate status summary 1998/1999. International Council for the Exploration of the Sea, Copenhagen

ICES (2000) The annual ICES ocean climate status summary 1999/2000. International Council for the Exploration of the Sea, Copenhagen

ICES (2002) The annual ICES ocean climate status summary 2001/2002. Report No. 251, International Council for the Exploration of the Sea, Copenhagen

ICES (2003) The annual ICES ocean climate status summary 2002/2003. Report No. 259, International Council for the Exploration of the Sea, Copenhagen

ICES (2004) The annual ICES ocean climate status summary 2003/2004. Report No. 269, International Council for the Exploration of the Sea, Copenhagen

ICES (2005) The annual ICES ocean climate status summary 2004/2005. Report No. 275, International Council for the Exploration of the Sea, Copenhagen

ICES (2006) ICES Report on Ocean Climate 2005. Report No. 280, International Council for the Exploration of the Sea, Copenhagen

ICES (2007) ICES Report on Ocean Climate 2006. Report No. 289, International Council for the Exploration of the Sea, Copenhagen

Kirby RR, Beaugrand G, Lindley JA, Richardson AJ, Edwards M, Reid PC (2007) Climate effects and benthic-pelagic coupling in the North Sea. Mar Ecol Prog Ser 330:31-38

Kröncke I, Dippner JW, Heyen H, Zeiss B (1998) Long-term changes in macrofaunal communities off Norderney (East Frisia, Germany) in relation to climate variability. Mar Ecol Prog Ser 167:25-36

Kröncke I, Stoeck T, Wieking G, Palojärvi A (2004) Relationship between structural and functional aspects of microbial and macrofaunal communities in different areas of the North Sea. Mar Ecol Prog Ser 282:13-31

Lindley JA, Williams R, Hunt HG (1993) Anomalous seasonal cycles of decapod crustacean larvae in the North Sea plankton in an abnormally warm year. J Exp Mar Biol Ecol 172:47-65

Niermann U, Bauerfeind E, Hickel W, Westernhagen HV (1990) The recovery of benthos following the impact of low oxygen content in the German Bight. Neth J Sea Res 25: 215-226

Submitted: February 14, 2008; Accepted: September 18, 2008
Nottage AS, Perkins EJ (1983) The biology of solenette, Buglossidium luteum (Risso), in the Solway Firth. J Fish Biol 22:21-27

> Ottersen G, Planque B, Belgrano A, Post E, Reid PC, Stenseth NC (2001) Ecological effects on the North Atlantic Oscillation. Oecologia 128:1-14

> Otto L, Zimmerman JTF, Furnes GK, Mork M, Saetre R, Becker G (1990) Review of physical oceanography of the North Sea. Neth J Sea Res 26:161-238

Reid PC (2005) Atlantic wide regime shift. Globec Int Newsl 11(2):9-10

Reid PC, Edwards M (2001) Long-term changes in the fishery, pelagos and benthos of the North Sea. Senckenb Marit 31: $107-115$

Reid PC, Edwards M, Hunt HG, Warner J (1998) Phytoplankton change in the North Atlantic. Nature 391:546

Reid PC, Borges Md F, Svendsen E (2001) A regime shift in the North Sea circa 1988 linked to changes in the North Sea horse mackerel fishery. Fish Res 50:163-171

Reid PC, Edwards M, Beaugrand G, Skogen M, Stevens D (2003) Periodic changes in the zooplankton of the North Sea during the twentieth century linked to oceanic inflow. Fish Oceanogr 12:260-269

Reiss H, Kröncke I (2004) Seasonal variability of epibenthic communities in different areas of the southern North Sea. ICES J Mar Sci 61:882-905

Reiss H, Kröncke I, Ehrich S (2006a) Estimating catch efficiency of a $2 \mathrm{~m}$ beam trawl for sampling epifauna by removal experiments. ICES J Mar Sci 63:1453-1464

Reiss H, Meybohm K, Kröncke I (2006b) Cold winter effects on benthic macrofauna communities in near- and offshore regions of the North Sea. Helgol Mar Res 60:224-238

Schröder A (2005) Community dynamics and development of soft bottom macrozoobenthos in the German Bight (North Sea) 1969-2000. Rep Polar Res 494:1-181

Stenseth NC, Mysterud A, Ottersen G, Hurrell JW, Chan KS, Lima M (2002) Ecological effects of climate fluctuations. Science 297:1292-1296

- Tyler PA (1977) Seasonal variation and ecology of Gametogenesis in the genus Ophiura (Ophiuroidea: Echinodermata) from the Bristol Channel. J Exp Mar Biol Ecol 30: 185-197

Tyler PA, Banner FT (1977) The effect of coastal hydrodynamics on the echinoderm distribution in the sublittoral of Oxwich Bay, Bristol Channel. Estuar Coast Mar Sci 5: 293-308

Ursin E (1960) A quantitative investigation of the echinoderm fauna of the central North Sea. Meddelelser fra Danmarks Fiskeri-Og Havundersogelser 2:1-204

- Vistisen B, Vismann B (1997) Tolerance to low oxygen and sulfide in Amphiura filiformis and Ophiura albida (Echinodermata: Ophiuridea). Mar Biol 128:241-246

Ziegelmeier E (1970) Über Massenvorkommen verschiedener makrobenthaler Wirbelloser während der Wiederbesiedlungsphase nach Schädigungen durch 'katastrophale' Umwelteinflüsse. Helgol Wiss Meeresunters 21:9-20 